\title{
Innovation Capital and its Measurement
}

\section{Tomasz Kijek*}

\begin{abstract}
Innovation capital regarded as an element of intellectual capital reflects the ability of an organization to create and commercialize the new knowledge (innovations). The aim of this study is twofold. Firstly, an attempt is made to give a concise review of innovation capital concept and its measures in selected intellectual capital - IC -models. Secondly, this paper sets out to extend the current models and introduce a new valuation method of innovation capital. Moreover, the paper provides empirical evidence about the use of the proposed method.

Keywords: innovation capital, knowledge assets, intellectual capital, measurement.
\end{abstract}

\section{Introduction}

With the increasing importance of new knowledge, innovation capital has become the core of intellectual capital providing a powerful drive for gaining and sustaining competitive advantage (Sullivan, 1998). The results of recent studies (Wang, 2011; 2012; Chang and Hsieh, 2011) using R\&D as a proxy for innovation capital have unambiguously shown the positive relationship between innovation capital and the firms' performance. Strategy literature derived from the resource-based theory (Wernerfelt 1995; Barney 1997) states that in order to fulfill a sufficient condition for effective managing and extracting value from innovation capital it is necessary to recognize and measure its elements (Castro et al., 2010). A few authors (i.e. Edvinsson and Malone, 1997; Wagner and Hauss, 2000; McElroy, 2002; Chen, Zhu, and Xie, 2004) have tried to define innovation capital in a distinct way and propose their own categorization of the concept. The definitions of innovation capital differ from one another with relation to the defining perspective (i.e. technological, organizational or sociological) and the scope of categorization of innovation capital. The differences in the definitions of innovation capital lead to different approaches to measuring it. But what is common to all the measurement methods is that they measure only particular elements of innovation capital, not the concept as a whole. Given this, the paper is intended as a review of the literature available on defining and measuring innovation capital, as well as it introduces and validates a new valuation model of innovation capital.

* Dr Tomasz Kijek, University of Life Sciences, tomasz.kijek@up.lublin.pl. 
The proposed methodology of estimating the value of innovation capital is based on the assumption that it is possible to funnel a part of the value of intellectual capital to the value of innovation - generating knowledge assets. In the valuation procedure innovation capital represents a multiplicative function/equation of three elements, i.e. the value of intellectual capital, an extracting coefficient and an efficiency coefficient. The first coefficient allows for extracting the value of innovation capital from the value of intellectual capital. The second coefficient represents what in Edvinsson and Malone's (1997) terminology is called "the truth detector" of the equation. Details on each step of the estimation procedure are provided in the next section of the paper.

\section{Definitions of innovation capital}

Innovation capital is a term that arises from a conjunction of two seminal economic concepts, i.e. capital and innovation. The former is treated in neoclassical capital theory as a factor of production that enters as an input into resources transformation process (Birner, 2002). Most contemporary economists assume that there are two kinds of capital included in the production function models, i.e. physical capital and human or knowledge capital, both of which are accumulable (Arestis, Palma and Sawyer, 1997). The stock of capital can render different productive services that affect its value. The latter can be understood as a process (Trott, 1998; Tödtling, Lehner and Kaufmann, 2009) or an effect (Dosi, 1992; Adams, Bessant and Phelps, 2006). In the first approach, innovation consists of all the decisions and activities that occur from the recognition of a need or a problem, through research, development and commercialization of an invention (Rogers, 2003, p. 137). In the second approach, innovation means the introduction of a new or significantly improved product (or service), process, marketing method or methods in organizational practices within a company, in the workplace or in foreign affairs (OECD, 2005, p. 46). In the light of the presented meanings of the concepts of innovation and capital, innovation capital is a bundle of the firm's resources/assets that renders complementary services in the process of new knowledge (innovation) creation and commercialization. This definition sensu largo can be further detailed on the basis of intellectual capital - IC -theory.

There is no generally accepted definition of innovation capital in IC literature. One of the earliest definitions is given by Edvinsson and Malone (1997). They describe innovation capital as renewal capabilities of a company in the form of intellectual properties and other intangible assets used to create and introduce new products and services to the market. There are other definitions of innovation capital that not only benefit from Edvinsson and Malone's approach but also add new concepts such as learning, culture, technology and networks that are crucial in the new product/service development process. Table 1 summarizes some of the definitions of innovation capital introduced in IC literature. 
Table 1. Definitions of innovation capital

\begin{tabular}{ll}
\hline \multicolumn{1}{c}{ Definition } & \multicolumn{1}{c}{ Authors } \\
\hline $\begin{array}{l}\text { The competence of organizing and implementing R\&D, unremittingly } \\
\text { bringing forth a new technology and a new product to meet customers' } \\
\text { demands. }\end{array}$ & Chen et al. (2004) \\
\hline $\begin{array}{l}\text { The capabilities of a company to generate value in the future. It contains } \\
\text { the component development of processes, products and services, but } \\
\text { also technology and management issues. }\end{array}$ & $\begin{array}{l}\text { Wagner and Hauss } \\
(2000)\end{array}$ \\
\hline $\begin{array}{l}\text { The ability of a company to develop new products, as well as any } \\
\text { creative ideas. }\end{array}$ & Tseng and Goo (2005) \\
\hline $\begin{array}{l}\text { A particular archetypical social pattern which aims at production, } \\
\text { diffusion and application of new knowledge by, and for, an organization. }\end{array}$ & McElroy (2002) \\
\hline $\begin{array}{l}\text { Direct consequence of the company's culture and its ability to create } \\
\text { new knowledge from the existing base. }\end{array}$ & Joia (2004) \\
\hline $\begin{array}{l}\text { The combination of organizational knowledge necessary to develop } \\
\text { future technological innovations. }\end{array}$ & $\begin{array}{l}\text { Castro, Verde, Saez and } \\
\text { Lopez (2010) }\end{array}$ \\
\hline
\end{tabular}

The analysis of these definitions allows for the identification of key features of innovation capital that can be described as follows:

1. Its intangibility.

2. Its potential to create value in the future.

3. Its reliance on technologically as well socially as embedded knowledge.

4. Its excludability by property rights and trade secrets.

Moreover, these definitions provide a useful framework for the identification of innovation capital components.

\section{Elements of innovation capital}

In the resource-based view of a firm, innovation capital, treated as the ability of a company to create and commercialize innovations, can be regarded as a bundle of assets and, more generally, resources. An asset/resource is strategic if it fulfills the requirements of being valuable, seldom, immobile and not substitutable (Barney, 1997). As previously stated, innovation capital possesses attributes that make it a "strategic asset". For the purpose of identifying innovation capital assets, it is important to specify the nature of these assets in relation to the new knowledge (innovation) generation and commercialization process.

According to Edvinsson and Malone (1997), innovation capital consists of two components, i.e. intellectual property - IP and other intangible assets. Intellectual property represents legally protected and codified knowledge that can be viewed as business assets (Sullivan, 2000). Urbanek (2008) groups IP rights into two bundles, i.e. creative IP rights (e.g. trademarks, author rights) and innovative IP rights (i.e. utility models, patents). The latter exist in order to protect an invention that meets three requirements for a patent: novelty, non-obviousness and usefulness. In general, invention is the first occurrence of an idea for a new product or process, while innovation is the first commercialization of the idea (Fagerberg, 2004, p. 4). Invention 
is mainly the result of $R \& D$ activity defined as creative work carried out on a systematic basis in order to increase the stock of knowledge and the use of this knowledge to devise new applications (OECD, 2002, p. 28). It is important to note that International Accounting Standards No 38 - IAS 38 - differentiate between the research and the development phases. This separation causes that the research phase, providing (general) new scientific or technical knowledge and understanding, is, in terms of IFRS, not regarded as an investment, which conflicts with the resource-based view of innovation capital (Günther, 2010, p. 323). From the resources perspective, both innovative IP rights and R\&D are in most cases the technological, codified (registered and unregistered) knowledge assets in a portfolio of innovation capital.

Another group of the elements of innovation capital consists of intangibles that are in most cases non-technological and embodied in the organizational routines and thinking of the employees. These elements can be described as follows:

1. Innovation strategy that relates to strategic choices a firm makes regarding its innovation (Ramanujam and Mensch, 1985), i.e. the selection of the type of innovation that fits best the firm's objectives and the allocation of resources to different types of innovations.

2. Innovation culture that is the mixture of the innovation-related attitudes, experiences, beliefs and values of the employees (Sammerl, 2006, after: Schentler, Lindner and Gleich, 2010, p. 307). Innovation culture has an integrating function and stimulates innovation activities.

3. Innovation structure that encompasses both the innovation process organization (i.e. roles, responsibilities, steps, etc) and the way the employees engaged in the innovation are grouped (Adams et al., 2006, p. 33).

4. Knowledge (technological and non-technological) possessed by the employees engaged in the innovation process. This knowledge is tacit to varying degrees. The stock of knowledge can be increased by internal and external learning of an organization (Schentler et al., 2010, p. 308). Internal learning refers to the creation of new knowledge within the enterprise, while external learning pertains to the integration of knowledge from outside the enterprise.

Figure 1 shows that innovation capital assets render services in the innovation process in combination with other assets of a firm such as physical assets, financial assets and other intangible assets. The theory and practice of the innovation process indicate that for a successful implementation of new inventions, the organization requires both the physical backup, i.e. machinery, equipment and buildings, and the financial one (Dodgson, Gann and Salter, 2008). In relation to the intangibles employed in the innovation process, Wagner and Hauss (2000) point to the dynamic interactions between the innovation capital's assets and other types of intangible assets. They also stress that effective implementation of innovations depends on the use of all kinds of intangibles in innovation activity. 


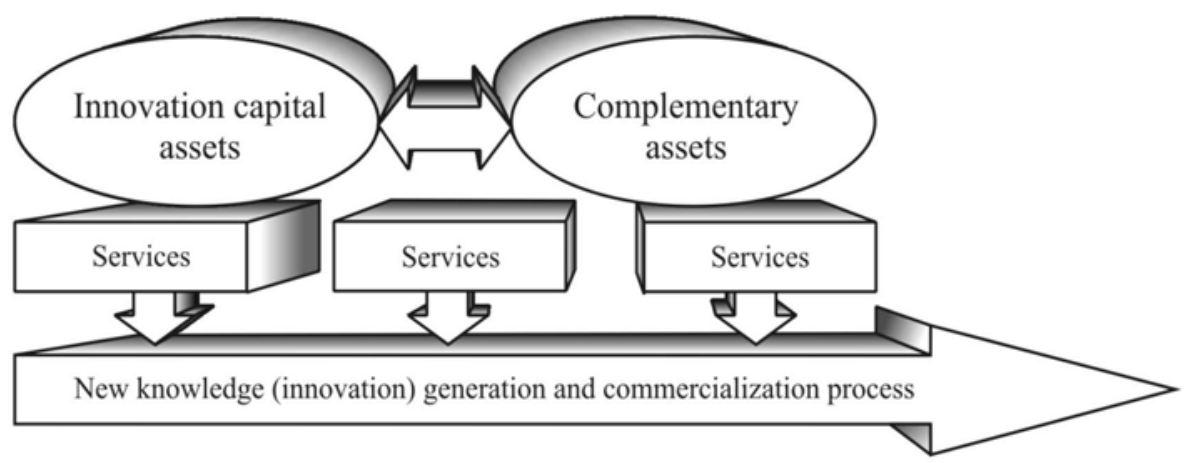

Figure 1. Innovation capital and complementary assets in new knowledge creation and commercialization process

To sum up, innovation capital consists of a set of resources/assets that can be regarded either as static knowledge - potential input to the knowledge transformation process, or dynamic knowledge - in transformation, and finally as the results of the knowledge transformation process. Under this approach, the stocks of innovation capital elements can be increased by knowledge flow from inside or/and outside of the company. For technological assets Dierickx and Cool (1989) made the distinction between the stock of technological know-how and R\&D expenditure, treated as the knowledge flow, using "bathtub" metaphor. The fact that know-how depreciates over time induces R\&D spending. In case of non-technological and uncodified knowledge assets counting of their stocks is extremely difficult. However, given the nature of these assets, Johnson (1999) argues that the use of sociological measurements may be most appropriate in this case.

\section{Measurement of innovation capital}

In order to manage innovation capital rationally it must be measured and reported upon. The issue of measuring innovation capital is important as much as it is used to develop innovation capital assets and estimate their effect on a firm's performance (Kaplan and Norton, 1996). Therefore, there is a pressing need to measure innovation capital from the perspective of internal decision making. Moreover, innovation capital measurement is necessary for communication with external shareholders (Mourtisen, Bukh and Marr, 2005), especially with investors seeking information on future performance of companies. It is important to stress that the measurement of innovation capital is difficult, since innovation capital assets are often context specific and interconnected (Marr and Spender, 2004).

Measurement of the innovation capital regarded as a component of intellectual capital can be performed with direct methods - DIC - and scorecard methods- SC (Roos, Pike and Fernström, 2005). Financial indicators are used as a part of the direct methods to assess the value of the elements of intellectual capital, whereas in case 
of the scorecard methods, non - financial indicators and indices are used. Table 2 presents lists of indicators of innovation capital in both the non - financial approach and the financial one.

Table 2. Indicators of innovation capital

\begin{tabular}{ll}
\hline \multicolumn{1}{c}{ Approach } & \multicolumn{1}{c}{ Indicators } \\
\hline Non - financial & Number of new products/processes introduced in the last three years \\
& Average time of new product/process development \\
& Number and quality of patents or patent claims \\
& Number and quality of R\&D employees \\
& Cooperation between R\&D, production and marketing departments \\
& Propensity to exchange of knowledge in social networks \\
& Management's support for innovation culture \\
& Management ability to deal with innovation projects \\
& Incentives for innovative employees \\
& High management support for innovation \\
\hline Financial & R\&D expenditures \\
& Sale of new products \\
Income from the licensing fees
\end{tabular}

Source: Chen et al. (2004), Wu, Chen and Chen (2010) and Günther (2010)

In case of certain elements of innovation capital, such as patents and R\&D, it is possible to calculate their monetary value using the following approaches (Krostevitz and Scholich, 2010):

- Cost approach, which is based on cost assessment of an asset according to the costs needed to reproduce it or to duplicate it.

- Market approach, which assumes that the value of an asset can be derived from prices obtained for similar assets in the market.

- Income approach, which estimates the value of an asset by calculating the present value of future cash flows which are expected to be generated by the asset.

- Real option approach, which assumes that an asset provides the company with a range of different options. This flexibility allows the managers to avoid rigid decisions. The best known financial option pricing model is the Black-Scholes model (Sudarsanam et al., 2005).

\section{New valuation model of innovation capital-foundations and calculation procedure}

The literature review on the valuation models of intangible assets provided by Sveiby (2010) indicates that there is a lack of a model that estimates the aggregated value of innovation capital at this point in time. For example, Sullivan's (2000) Intellectual Asset Valuation - IAV model or Dow Chemical's Citation- Weighted Patents method (Bontis, 2001) allow for evaluation of the innovative IP rights but are insufficient for valuation of innovation capital as a whole. In turn, some of comprehensive IC measurement models 
such as Skandia Navigator (Edvinsson and Malone, 1997) or IC index (Roos, Roos, Dragonetti and Edvinsson, 1997) tend to use and aggregate more or less consistent sets of measures of a firm's renewal and development capacity (innovation capital), but they are unable to give a direct financial value of innovation capital, which can be easily understood and interpreted by the firm's stakeholders. In order to reduce this gap in the literature on IC measurement, a new valuation model of innovation capital is introduced. Intentionally, the model is supposed to be an alternative for measurement models of innovation related intangibles, which take a narrow assets perspective or use different indices aggregated in non-financial manner.

The proposed methodology has different areas of applicability that range from external reporting to stakeholders, through comparison among firms within the same industry to management of innovation capital. The new valuation model deploys widely accepted approaches to valuation of intellectual capital, such as (Sveiby, 2010):

- Calculation of the overall value of intangible assets, using market capitalization methods or return on assets methods.

- Measurement of various components of intangible assets, using scorecard methods or direct intellectual capital methods.

At the model's foundation is a definitional assumption that intellectual capital equals the sum of human capital, structural capital, including innovation capital, and market capital that are merely labeled differently in various IC models (Bounfour, 2002). The additive form of IC concept gives the important implications for the field of IC measurement, since on the one hand it allows for a split-up of IC into a few dimensions and use of different measures covering major focus perspectives, and on the other hand it provides an opportunity for the consolidation of all the individual indicators into a single index on a firm (Roos et al., 1997) or national level (Bontis, 2004). The main problem with aggregation and disaggregation of IC elements measured in monetary terms is the choice of measurement structure. M'Pherson and Pike (2001) argue that the additive rule for value combination is the exception and suggest using conjoint measurement structures, e.g. polynomials that satisfy the combined value measurement requirement. Unfortunately, the authors do not provide convincing examples of how to measure the value effect of company's resources interaction. In turn, Roos et al. (1997) and Schweihs and Reilly (1999) propose the employment of the additive rule $(1+1=2)$ used as a pragmatic necessity in the aggregated value calculation. In spite of these controversies, the additive rule for the IC value calculation is the main point in the proposed model.

The procedure of value calculation in this model is essentially defined by three stages:

1. In the first step of the algorithm the value of intellectual capital is calculated. The choice of valuation method at this stage is extremely important, since it has a direct impact on the next steps and determines the final result of valuation. In general, the use of a specific measurement method depends on such factors as purpose, situation and audience of measurement (Sveiby, 
2010). Moreover, accurate, useful and defensibility of valuation requires the selection of a methodology applied with as much analytical rigor as the sources of input data will allow (Sullivan, 1998). For the proposed model, the choice of IC valuation method is limited to the market capitalization methods (e.g. Tobin's $Q$ model or the market value less the book value method) and return on assets methods (e.g. KCE model (Lev and Gu, 2011) or CIV model (Stewart, 1997)). The methods assigned to the first group are often applied for an initial valuation of intangibles in situations of cross-companies comparisons, mergers and acquisitions or stock market valuations. Their support for management decisions making is constrained to an organization's level only (Skyrme, 2003). The methods of the second group are used in similar situations as market capitalization methods but they are regarded as being more sophisticated and formally rigorous. Considering the fact that the application of different methods results in values which differ, it would be recommended to utilize more than one valuation method for a comparative purpose.

2. The second stage in innovation capital valuation is the extraction of the value of innovation capital from the value of intellectual capital. This step is grounded in the additive rule for value calculation. The proxy for the extracting coefficient is the share of new products sales in relation to total sales. This coefficient is a direct measure of the exploitation of innovation capital and funnels part of the value of intellectual capital to the value of innovation capital. It relates to innovations that were introduced into the market and that resulted in a positive cash-flow (Kleinknecht, Montfort and Brouwer, 2002). By far the share-in-sales of new products or services is one of the most commonly used measures of a firm's innovativeness and is widely applied in empirical research (Crépon, Duguet and Mairesse 1998).

3. The assessment of innovation capital efficiency. The efficiency coefficient represents how effectively an organization is currently using its innovation capital and can be treated as a proxy for the quality of innovation capital's assets. The roots of the efficiency coefficient can be found in the work of Edvinsson and Malone (1997) and according to them, it captures a firm's velocity, position and directions. Efficiency in this model is defined as the ratio of the results of innovation capital exploitation (e.g. number of innovations or sales of new products or services) to innovation capital's assets. For the sake of calculation correctness, the coefficient must be normalized. The method that provides relative efficiency with multiple inputs and outputs is DEA (Data Envelopment Analysis). The DEA efficiency of the firm is measured by estimating the ratio of virtual outputs to virtual inputs in relation to the group of homogonous firms Decision Making Units (Cooper, Seiford and Tone, 2007). DEA has been widely used in many application areas, but recently some authors, e.g. Kijek (2010), Chen and Lu (2006), have proposed to use DEA to measure the efficiency of innovation activity at the firm level. 
Figure 2 presents the structure of the model in the form of mathematical relationships among its elements.

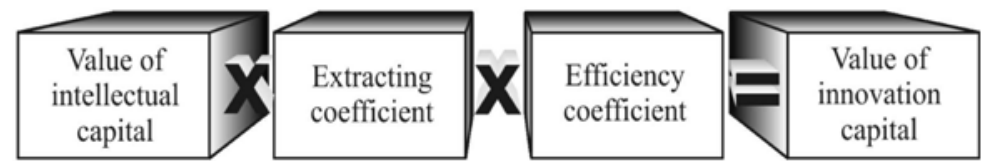

Figure 2. Elements and structure of the model

The underlying simplicity of the model allows the researchers and practitioners to adopt it in a variety of firms and sectors. The model is especially useful for knowledge based companies where the innovation intangibles form the core assets. What is important, it provides managers and other stakeholders with the financial value of innovation capital, which is especially useful for them. Moreover, the model fulfils other Lynn's (1998) criteria for measuring intellectual capital, i.e.: it is based on information that is currently accessible, it uses measures that are understandable and relevant, it proposes proxies for the quality data that constitute the measured concept.

However, there are a few drawbacks of the model. The most obvious flaw is that this method is static and relies on ex post values. Nevertheless, the model gives an opportunity to extrapolate and validate the value of innovation capital into the future. Moreover, some controversies may arise from the concept and the calculation of the extracting coefficient. Firstly, the coefficient concept relies on the assumption that the value of intellectual capital can be separated into additive elements, ignoring the fact that the synergy of intangibles has a significant share in value creation. Secondly, the allocation key is arbitrary, since innovation capital allows the company to introduce not only new products/services but also other types of innovation. What is more, the coefficient is sensitive to the "age" of the firm, especially in case of start-up companies with an extremely high level of new product revenues. It is clear that the model has its strengths and weaknesses, and that there is a possibility for its improvement.

\section{Methodology and results of research}

In order to test the new method for the valuation of innovation capital, an empirical study has been conducted. In the first stage of the study the test sample has been selected. The sample includes 9 companies from IT industry listed on NewConnect market - Polish Alternative Stock Exchange. The companies have been ranked by investors among the 25 most innovative firms listed on the NC market. The sample selection was purposive, since it was important for the study to be conducted on a set of firms rich in innovation capital. As it is known, companies in the IT sectors actively invest in innovation capital, which results in a high level of their innovativeness. The IT industry is classified as a knowledge-intensive industry, where the lifespan of technology is quite short and new product introductions are frequent. As a consequence, this industry has been often chosen for studies on intellectual capital 
(Wang and Chan, 2005) and innovation (Goswami and Mathew, 2005). Moreover, the sample has been determined by model assumptions, especially by the firms' homogeneity requirement and by the requirement of the minimum number of DMUs in the DEA analysis (Emrouznejad and Gholam, 2009).

According to the procedure of value calculation of innovation capital within the model, the first step is the valuation of intellectual capital. This has been carried out by using

the KCE model based on the classical economic theory of production function. Under this approach, the value of intellectual capital is estimated by subtracting the normal returns on physical and financial assets, from the economic performance measure - normalized earnings. The residual then becomes the contribution of intangible assets. Capitalizing the expected stream of intangibles-driven earnings over future years gives an estimate of "intangible capital." The model formula is as follows:

$$
V I C=\left(N E-\alpha^{*} P A-B^{*} F A\right) / \gamma
$$

where: VIC - value of intellectual capital (intangible capital), $N E$ - normalized earnings, $P A$ - physical assets, $F A$ - financial assets, $\alpha$ - normal rate of return on physical assets, $B$ - normal rate of return on financial assets, $\gamma$ - discount rate of intellectual capital.

The interpretations of the model variables, i.e. normalized earnings, physical assets and financial assets, have been adapted from Kasiewicz, Rogowski and Kicinska (2006). The model parameters, i.e. normal rates of return on physical and financial assets and a discount rate for intangibles-driven earnings, have been calibrated using the values of coefficients proposed by Lev and Gu (2011). To determine the normalized earnings I have used three-year historical data (i.e. the years 2008-2010).

Next, the extracting coefficient has been calculated as the ratio of the sales of the new products or services (introduced in the years 2007-2008) to the total sales in the year 2010. The lag between the period of the introduction of new products or services and the relative sale effects of these innovations is consistent with a methodology of gathering data of firms' innovation activity for making the NewConnect Innovativeness Ranking. The data provided by the ranking participants have been used in the study.

In order to calculate the efficiency of the firms, the output-oriented BCC model proposed by Banker et al. (1984) has been employed. This model assumes variable returns to scale The output orientation of the model in the study results from the assumption that the objective of the exploitation of innovation capital is to increase outputs. The model deals with one input and two outputs:

x_1j- R\&D expenditure in the years 2007-2008 (as percentage of total sales).

$y \_1 j$ - the number of new products or services introduced in the years 2007-2008.

$\mathrm{y} \_2 \mathrm{j}$ - the revenues from new products or services (introduced in the years 20072008) in the year 2010. 
The model can be expressed by the following mathematical formulation:

$\psi_{-} 0=\max \psi$,

s.t.:

$\sum_{j=1}^{n} y_{r i} \lambda_{j} \geq \psi y_{r 0}$,
$\sum_{j=1}^{n} x_{i j} \lambda_{j} \leq x_{i 0}$,
$\sum_{j=1}^{n} \lambda_{j}=1$,
$\lambda_{j} \geq 0$.

where DMUo represents one of the $n$ DMUs under evaluation, and $x_{i o}$ and $y_{\text {ro }}$ are the ith input and $r$ th output for $\mathrm{DMU}_{0^{\prime}}$, respectively. If $1 / \psi^{*}=1$, then the firm under evaluation is efficient. Otherwise, if $0<1 / \psi^{*}<1$ the firm is inefficient, i.e., this firm can increase its output levels. The efficiency scores in this study have been estimated using the program DEAP Version 2.1. Table 3 summarizes the results of the valuation of innovation capital in the selected sample of the firms.

Table 3. Values of firms' innovation capital

\begin{tabular}{ccccc}
\hline Firm & $\begin{array}{c}\text { Value of intellectual } \\
\text { capital } \\
\text { [in million EUR] }\end{array}$ & $\begin{array}{c}\text { Extracting } \\
\text { coefficient }\end{array}$ & $\begin{array}{c}\text { Efficiency } \\
\text { coefficient }\end{array}$ & $\begin{array}{c}\text { Value of innovation } \\
\text { capital } \\
\text { [in million EUR] }\end{array}$ \\
\hline A & 3.85 & 0.65 & 1.00 & 2.50 \\
B & 3.15 & 0.04 & 1.00 & 0.13 \\
C & 0.34 & 0.47 & 0.34 & 0.05 \\
D & 0.26 & 0.44 & 0.68 & 0.08 \\
E & 1.46 & 0.85 & 0.58 & 0.72 \\
F & 0.91 & 0.38 & 0.32 & 0.11 \\
G & 0.25 & 0.52 & 0.69 & 0.09 \\
H & 0.92 & 0.08 & 0.71 & 0.05 \\
I & 0.47 & 0.84 & 1.00 & 0.39 \\
Mean & 1.29 & 0.47 & 0.70 & 0.46 \\
Std. Dev. & 1.25 & 0.27 & 0.25 & 0.75 \\
\hline
\end{tabular}

Within the sample, the values of the firms' innovation capital differ to a great extent. For firm A with the highest value of innovation capital, the reasons for its classification are quite simple to understand and can be posited as being primarily threefold. Firstly, the firm has the highest value of intellectual capital. Secondly, its extracting coefficient is quite high. Finally, the firm is efficient in the exploitation of innovation capital. The problem that may arise from the calculation procedure in this case is the size effect. A common solution to this problem is to deflate the value of intellectual capital (Abeysekera, 2011). Nevertheless, in case of other firms the size effect is balanced by the extracting coefficient and the efficiency coefficient. For instance, the second - largest firm by the value of intellectual capital (i.e. firm B) has a relatively low value 
of innovation capital in relation to the leader because of its extremely low level of the extracting coefficient. As mentioned previously, the efficiency coefficient also affects the value of innovation capital to a significant extent. There are three efficient firms in the sample (i.e. firms A, B and I) and for the rest of them the values of the coefficients are less than one and indicate their level of inefficiency. Moreover, on the basis of the efficiency coefficient it is possible to measure the potential value of innovation capital, assuming efficiency of all firms.

The results of calculations of the values of innovation capital can be regarded as either strategic or operational objectives of innovation capital management. For example, the firms with extremely low values of the extracting coefficient and high values of the efficiency coefficient (i.e. firms $B$ and $\mathrm{H}$ ) should focus their attention on how to reformulate the innovation strategy to achieve the potential value of innovation capital. In turn, the firms that are inefficient in exploiting their innovation potential (i.e. firms $\mathrm{C}$ and $\mathrm{F}$ ) ought to analyze the process of innovations implementation and identify the areas, i.e. the elements of innovation capital, for improvement.

Summarizing the results of the research, it should be noted that they are limited to the sample firms. The study allows for illustrating how the model helps to reveal the value of intangible assets rendering services in the innovation process. Moreover, the research findings supply the opportunity to identify "best practices" in relation to the exploitation of innovation capital within the sample. Although the model provides a rough value of innovation capital, the results of its application may be a starting point for a further, more detailed, valuation of the elements of innovation capital.

\section{Conclusions}

This paper produces a few important contributions to the theory of innovationrelated intangibles. Theoretical implications of this work concern two subject areas: the literature on defining and categorization of innovation capital and the literature on measuring innovation capital.

In the first case, the paper provides the working definition of innovation capital, derived from the theory of capital and the theory of innovation, and identifies its key features. In addition, this work offers a new classification of the innovation capital's elements. The proposed classification goes beyond the narrow focus approaches, typical for most of IC models, since it includes a broad set of knowledge assets ranging from the technological assets to the tacit knowledge embedded in employees.

In the second case, this paper introduces a new valuation model of innovation capital with its own calculation procedure. The new valuation model is based on the assumption that it is possible to funnel a part of the value of intellectual capital to the value of innovation capital. The model consists of a three - stage algorithm. The value of innovation capital is estimated as a result of multiplying three elements, i.e. the value of intellectual capital, the extracting coefficient and the efficiency coefficient. From the methodological point of view, the method is an incremental innovation in the literature on intangibles measurement, but underlying simplicity of the model makes 
it useful for managers and other stakeholders and as Skyrme (2003) comments on the stage of IC measurement development: "Here, simplicity can be a virtue" (p. 239).

Considering the managerial implications, it is worth emphasizing that the model use may facilitate the process of innovation capital management by increasing manager's understanding of the contribution of innovation capital into a company's performance. It seems to be extremely important for managers that innovation capital is measured in monetary terms in the model. This helps managers to focus their attention on the increase of the value of innovation-related intangibles. What is important, the results of the value of innovation capital estimation within the sample are useful in the processes of searching for best practices and identification of the areas and means of performance improvement. Moreover, the model provides more relevant information to investors and analysts on the company's innovation capacity than traditional, single measures of innovation capital such as R\&D or patents. Thus, the model may be deployed to a process of fundamental analysis to support the stock price forecasting.

The results of the model application in the sample of the IT firms are very interesting and can be regarded as an illustrative example of the model use. Moreover, the results of the study provide an opportunity to comparative analyses. Because this study has been conducted on the sample of the firms listed on the Polish alternative trading system, the results may be used as a benchmark for the comparison of the value of innovation capital of IT firms listed on other European or American alternative trading systems. Although the results seem to be informative, they have some limitations. Firstly, as previously noted, the model has been trialed with a limited number of companies form the IT industry. Secondly, the KCE model of calculating the value of intellectual capital has several drawbacks (Ujwary-Gil, 2009). Thirdly, the number of inputs (i.e. the elements of innovation capital) in DEA model used to estimate the efficiency coefficient is relatively small. Instead, there are several other elements of innovation capital beyond the scope of this study that may be included in DEA analysis.

Due to the above limitations, further research on the model application is needed. The interesting new pathways for the future are: extending the scope of research to work with a statistically significant sample, using other models of the valuation of intellectual capital in the first step of the valuation algorithm and broadening a set of inputs in the DEA method so as to include more elements of innovation capital in the process of estimating the efficiency coefficient. I believe that in this way the model may provide more accurate values of innovation capital. 


\section{References}

Abeysekera, I. (2011). The relation of intellectual capital disclosure strategies and market value in two political settings. Journal of Intellectual Capital, 12 (2), 319-338.

Adams, R., Bessant, J. and Phelps, R. (2006). Innovation management measurement: A review. International Journal of Management Reviews, 8 (1), 21-47.

Arestis, P., Palma, G. and Sawyer, G. (1997). Capital Controversy, Post-Keynesian Economics and the History of Economic Thought: Essays in Honour of Geoff Harcourt. London: Routledge.

Banker, R.D., Charnes, A. and Cooper, W.W. (1984). Models for the estimation of technical and scale inefficiencies in Data Envelopment Analysis. Management Science, 30, 1078-1092.

Barney, J. (1997). Gaining and Sustaining Competitive Advantage. New York: Addison Wesley Publishing Company.

Birner, J. (2002). The Cambridge Controversies in Capital Theory: A Study in the Logic of Theory Development. London: Routledge.

Bontis, N. (2001). Assessing knowledge assets: a review of the models used to measure intellectual capital. International Journal of Management Reviews, 3 (1), 41-60.

Bontis, N. (2004). National Intellectual Capital Index: A United Nations initiative for the Arab region. Journal of Intellectual Capital, 5 (1), 13-39.

Bounfour, A. (2002). The Management of Intangibles: The Organisation's Most Valuable Assets. London: Routledge.

Castro, G., Verde, M., Saez, P. and Lopez, J. (2010). Technological Innovation. An Intellectual Capital Based View. Basingstoke: Palgrave Macmillan.

Chen, J., Zhu, Z. and Xie, H. (2004). Measuring intellectual capital: a new model and empirical study. Journal of Intellectual Capital, 5 (1), 195-212.

Chen, T. and Lu, L. (2006). Innovation and the operational performance of IC design industry in Taiwan: a data envelopment analysis model. Paper presented at 15th International Conference on Management of Technology, Beijing, China.

Cooper, W., Seiford, L. and Tone, K. (2007). Data Envelopment Analysis. New York: Springer.

Crépon, B. Duguet, E. and Mairesse, J. (1998). Research, Innovation, and Productivity: an Econometric Analysis at the Firm Level. Economics of Innovation and New Technology, 7, 115-158.

Dodgson, M., Gann, D. and Salter, A. (2008). The Management of Technological Innovation: Strategy and Practice, Oxford: Oxford University Press.

Edvinsson, L., and Malone, M.S. (1997). Intellectual Capital: The Proven Way to Establish Your Company's Real Value by Measuring Its Hidden Brainpower. London: Judy Piatkus.

Fagerberg, J. (2004). Innovation: A Guide to the Literature. In: J. Fagerberg, D. Mowery and R. Nelson (Ed.), The Oxford Handbook of Innovation (pp. 1-25). Oxford: Oxford University Press. 
Günther, T. (2010). Accounting for Innovation: Lessons Learnt from Mandatory and Voluntary Disclosure. In: A. Gerybadze, U. Hommel, H.W. Reiners, and D. Thomaschewski (Ed.), Innovation and International Corporate Growth (pp. 319-332). Berlin: Springer.

Goswami, S. and Mathew, M., (2005). Definition Of Innovation Revisited: An Empirical Study On Indian Information Technology Industry. International Journal of Innovation Management, 9 (3), 371-383.

Kaplan, R.S., and Norton, D.P. (1996). The Balanced Scorecard: Translating Strategy into Action. Boston: Harvard Business School Press.

Kasiewicz, S., Rogowski, W. and Kicińska, M. (2006). Kapitał intelektualny. Spojrzenie z perspektywy interesariuszy. Warszawa: Oficyna Ekonomiczna.

Kijek, T. (2011). Evaluation of efficiency of enterprises' innovation activity. Economics and Organization of Enterprise, 1, 24-32.

Kleinknecht, A., Montfort, K. and Brouwer, E. (2002). The Non-Trivial Choice between Innovation Indicators. Economics of Innovation and New Technology, Vol. 11 No. 2, pp. 109-121.

Krostewitz, A. and Scholich, M. (2010). Modern Valuation Approaches for Corporate Innovation Activities. In: A. Gerybadze, U. Hommel, H.W. Reiners, and D. Thomaschewski (Ed.), Innovation and International Corporate Growth (pp. 263-280). Berlin: Springer.

Lev, B. and Gu, F. (2011). Intangible Assets: Measurement, Drivers, and Usefulness. In: G. Schiuma (Ed.), Managing Knowledge Assets and Business Value Creation in Organizations: Measures and Dynamics (pp. 110-124). Hershey: IGI Global.

Lynn, E. (1998). Performance evaluation in the new economy: bringing the measurement and evaluation of intellectual capital into the management planning and control system. International Journal of Technology Management, 16 (1-3), 162-176.

Marr, B. and Spender, J. (2004). Measuring knowledge assets - implications of the knowledge economy for performance measurement. Measuring Business Excellence, 8 (1), 18 - 27.

McElroy, M. (2002). Social innovation capital. Journal of Intellectual Capital, 3 (1), 30-39. Mouritsen, J., Bukh, P.N. and Marr, B. (2005). A reporting perspective on intellectual capital. In: B. Marr (Ed.), Perspectives on Intellectual Capital (pp. 69-81). Oxford: Butterworth-Heinemann.

M'Pherson, P. K. and Pike, S. (2001). Accounting, empirical measurement and Intellectual Capital. Journal of Intellectual Capital, 2 (3), 246-260.

OECD (2005). Oslo Manual: Guidelines for Collecting and Interpreting Innovation Data. Luxembourg: OECD Publishing.

OECD (2002). Frascati Manual 2002: Proposed Standard Practice for Surveys on Research and Experimental Development. Luxemburg: OECD Publishing.

Ramanujam, V. and Mensch, G.O. (1985). Improving the strategy-innovation link. Journal of Product Innovation Management, 2, 213-223.

Rogers, E.M. (2003). Diffusion of Innovations. New York: Free Press. 
Roos, J., Roos, G., Dragonetti, N.C. and Edvinsson, L. (1997). Intellectual Capital: Navigating in the New Business Landscape. London: Macmillan.

Roos, G., Pike, S. and Fernström, L. (2005). Managing Intellectual Capital in Practice. Oxford: Butterworth-Heinemann.

Sammerl, N. (2006). Innovationsfähigkeit und nachhaltiger Wettbewerbsvorteil: Messung, Determinanten, Wirkungen. Wiesbaden: DUV.

Schentler, P., Lindner, F. and Gleich, R. (2010). Innovation Performance Measurement. In: A. Gerybadze, U. Hommel, H.W. Reiners, and D. Thomaschewski (Ed.), Innovation and International Corporate Growth (pp. 299-317). Berlin: Springer.

Skyrme D. (2003). Measuring knowledge and intellectual capital. London: Optima Publishing.

Stewart, T.A. (1997). Intellectual Capital: The New Wealth of Organizations. New York: Doubleday.

Sudarsanam, S., Sorwar, G. and Marr, B. (2005). A Finance Perspective on Intellectual Capital. In: B. Marr (Ed.), Perspectives on Intellectual Capital, ButterworthHeinemann (pp. 56-68). Oxford: Butterworth-Heinemann.

Sullivan, P.H. (1998). Profiting from Intellectual Capital. Extracting Value from Innovation. New York: John Wiley\&Sons.

Sullivan, P.H. (2000). Value-Driven Intellectual Capital: How to Convert Intangible Corporate Assets Into Market Value. New York: John Wiley\&Sons.

Sveiby, K. (2010). Methods for Measuring Intangible Assets. Retrieved from http://www. sveiby.com/articles/IntangibleMethods.htm

Tödtling, F., Lehner, P. and Kaufmann, A. (2009). Do Different Types of Innovation Rely on Specific Kinds of Knowledge Interactions?. Technovation, 29, 59-71.

Trott, P. (1998). Innovation Management and New Product Development. London: Financial Times Management.

Tsen, C. and Goo, Y. (2005). Intellectual capital and corporate value in an emerging economy: empirical study of Taiwanese manufacturers. R\&D Management, 35 (2), 181-207.

Ujwary-Gil, A. (2009). Kapitał intelektualny a wartość rynkowa przedsiębiorstwa. Warszawa: C.H. Beck.

Urbanek, G. (2008). Wycena aktywów niematerialnych przedsiębiorstwa. Warszawa: PWE.

Wagner, K. and Hauss, I. (2000). Evaluation and Measurement of R\&D Knowledge in Engineering Sector. In: M. Khosrowpour (Ed.) Proceedings of the 2000 information resources management association international conference on Challenges of information technology management in the 21st century (pp. 709-712). Anchorage: Idea Group Publishing.

Wang, M. (2012). Could Innovation Capital impact On Firm Performance? Study by Panel Data Two Stage Regression with Board Composition. Applied Mechanics and Materials, (145), 430-435. 
Wernerfelt, B. (1995). The resource-based view of the firm: Ten years after. Strategic Management Journal, 16 (3), 171-174.

Wu, H., Chen, J. and Chen, I. (2010). Innovation capital indicator assessment of Taiwanese Universities: A hybrid fuzzy model application. Expert Systems with Applications, 37, 1635-1642.

\begin{abstract}
Polish)
Kapitat innowacyjny traktowany jako element kapitału intelektualnego odzwierciedla zdolność organizacji do tworzenia i komercjalizacji nowej wiedzy (innowacji). Podstawowe cele prezentowanego opracowania obejmujq przedstawienie syntetycznego przeglqdu literatury z zakresu definiowania, kategoryzacji i pomiaru kapitału innowacyjnego $w$ wybranych modelach kapitału intelektualnego oraz opracowanie i empiryczne zweryfikowanie nowej metody wartościowania niematerialnych aktywów innowacyjnych.

Słowa kluczowe: kapitał innowacyjny, aktywa wiedzy, kapitat intelektualny, pomiar.
\end{abstract}

